\title{
MAINTAINING AND MANAGING THE DIVERSITY OF THE LIVING COLLECTION AT THE ROYAL BOTANIC GARDEN EDINBURGH - A PERSONAL PERSPECTIVE
}

\author{
Tony Garn ${ }^{l}$
}

\begin{abstract}
In a botanic garden it is the record-keeping, the labelling and the facility to trace the lineage of individual plants that sets it apart from other gardens. The Royal Botanic Garden Edinburgh (RBGE) has a rich and diverse Living Collection of plants. It is important that visitors, staff and students have access both to the collection and to this information. One definitive way to achieve this is to promote the seasonal interest found in the Collection through images and descriptions. This paper contains a selection of colour images, descriptions and a discourse on the diversity of the Living Collection and its future management. In it, the importance of plants and their place in the institution of RBGE is highlighted and the author looks forward to the changing social, economic, technological and environmental conditions that will affect management's capacity to develop and maintain the collection as the 21 st century advances.
\end{abstract}

\section{BACKGROUND INFORMATION}

The Royal Botanic Garden Edinburgh (RBGE) has been collecting and growing plants since 1670 and can now boast nearly 350 years of history and a continually evolving plant collection: the Living Collection. The Garden is an ideal environment in which to observe and record plants and their characteristics. Having spent most of my working life at RBGE, first as a student and then as a Supervisor, I have had the opportunity and privilege to witness this evolution at first hand, and the account that follows records some of my feelings and observations.

To record the Living Collection, a catalogue has been produced at intervals throughout the history of the Garden and these document our ever-evolving Living Collection. The last volume of this was Catalogue of Plants (Rae et al., 2012). As a comprehensive list of plants grown at RBGE this is an historic record of the flow (and loss!) of plant material into the four Gardens which comprise RBGE, first at Edinburgh, but latterly also into Benmore, Logan and Dawyck. The four Gardens together provide a wide diversity of soils, microclimates and cultivated spaces in which to grow, nurture and observe these plants.

Botanic gardens are repositories for a wealth of plants, many unknown in the horticultural trade, that have caught the eye of dedicated plant collectors on their travels to often inhospitable terrain. Seed collected on these expeditions is, with the necessary international permits, sent back to the collectors' home botanic gardens. Grown on,

1. Tony Garn is a Garden Supervisor at the Royal Botanic Garden Edinburgh. Address: 20A Inverleith Row, Edinburgh, EH3 5LR, UK.

Email: T.Garn@rbge.org.uk 
the plants' characteristics are often different from those observed in the wild due to the regimes and conditions in the gardens. Once the flowering stage has been reached, the plant is sent to the herbarium for positive identification. Specimens are prepared, dried and mounted to be stored for future research. Labels are ordered and affixed to the growing specimen in the garden. At the start of this journey an accession number is given, which is the unique identifier that means the plant can be tracked from introduction to de-accession.

There are currently 35,833 accessions at RBGE and of these 59.6 per cent are of known wild origin, with 39.4 per cent verified to check their accurate identification (Cubey, pers. comm.). This wild origin figure is a testament to the skill and determination of past and present collectors who have travelled to many areas of the world.

Botanic gardens exist as both scientific collections of plants and as visitor attractions and they are managed in a way that caters for both functions, although management styles vary enormously between gardens and sometimes between functions. Managed or unmanaged, however botanic garden plant collections grow and develop, they are classified and verified and their sheer diversity deserves our respect and should be valued as an important part of our heritage just as much as museum artefacts.

Like many other botanic gardens, RBGE is also an educational resource, which is reflected in our mission statement: "to explore, conserve and explain the world of plants for a better future". By observing and identifying plants as they come into seasonal interest and making this information available to the public, the diversity of the Living Collection and its importance can be communicated to a wide audience. The RBGE website contains a "Season's Highlights" page (RBGE, 2017) with descriptions of plants that I have observed over the past ten years. It is just one educational output from the Collection and one that exists in tandem with all the formal, schools and recreational courses which are also offered.

The Catalogue of Plants is an inventory of our stock, but one that also details collector, provenance and other information about each accession. However, it could be considered quite dry by non-specialists and so developing a pictorial reference to accompany the description of the plants on the RBGE website, has allowed the content to come alive and let the information become of use to a wider audience. The Catalogue of Plants and Inventory of Seasonal Plants both recognise the contribution of all past and present plant collectors and horticulturists who have enhanced the Living Collection and, through that, the Garden's landscape.

\section{A SELECTION OF PLANTS}

Botanic gardens are, in effect, safe repositories of the Earth's plant biodiversity, each garden acting as a living reservoir of a botanical ark as well as an untapped resource for education, research and sustainable use. With the wealth of material to choose from, selecting one plant to represent each month of the year has been difficult; however over the decade 2006-2016 there were some memorable inclusions. The following descrip- 
tions are extracts from the monthly selections of plants which have been highlighted for the visiting public.

\section{January}

This is always the bleakest month in a garden, with poor weather and short days, but it can be made special with a planting of snowdrops. Galanthus 'Lady Beatrix Stanley' (Fig. 1) is often the first snowdrop of the season and heralds the promise of spring. Snowdrops remind us that the days are lengthening and the sun will eventually warm the air and dry the soil. This cultivar has G. caucasicus parentage, with double flowers, white outer petals and the inner ones spotted green at the tips. The leaves have a glaucous bloom.

Take a look around when the sun is low in the sky and lighting up the lichens on deciduous tree bark. Xanthoria parietina (Fig. 2) can be found on the bark of Tapiscia sinensis - it also grows throughout the Arctic, adding a much needed splash of colour to the white surroundings. The Polar Inuit of Northern Greenland call it sunain anak, meaning 'sun's excrement'.

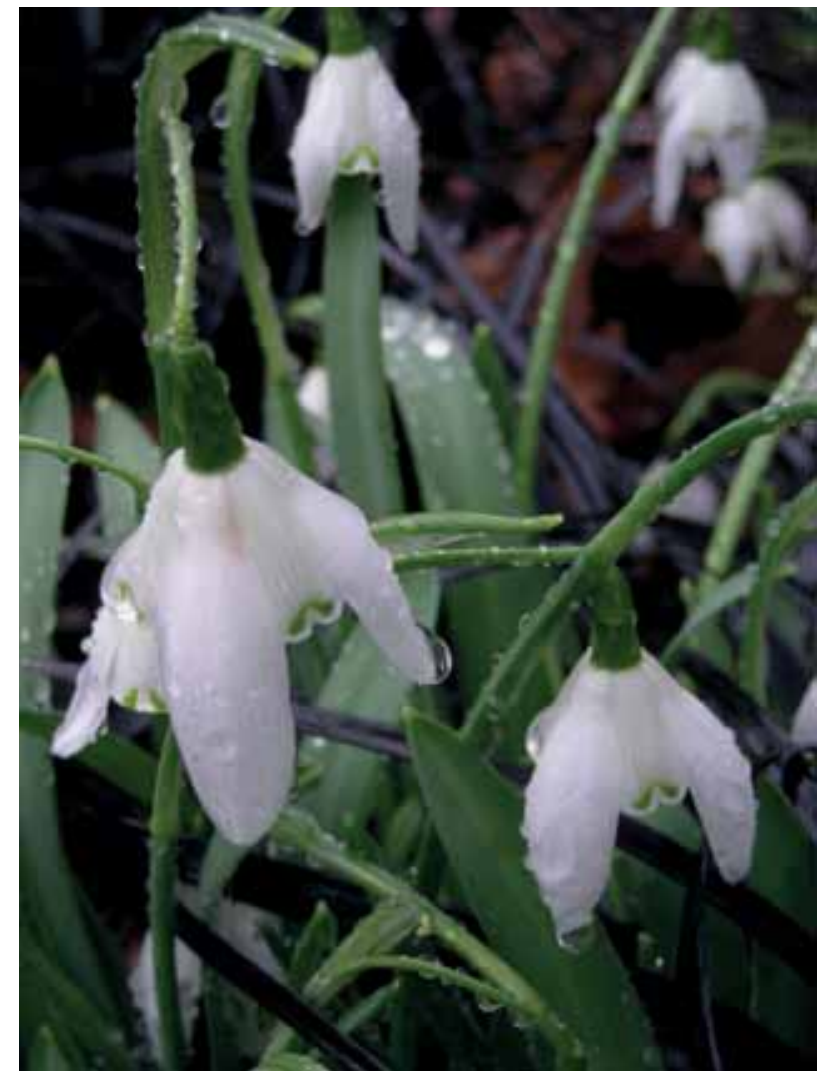

Fig. 1 Galanthus 'Lady Beatrix Stanley' 19694438. One of the earliest snowdrop cultivars to flower, often from late December. Photo: Tony Garn. 


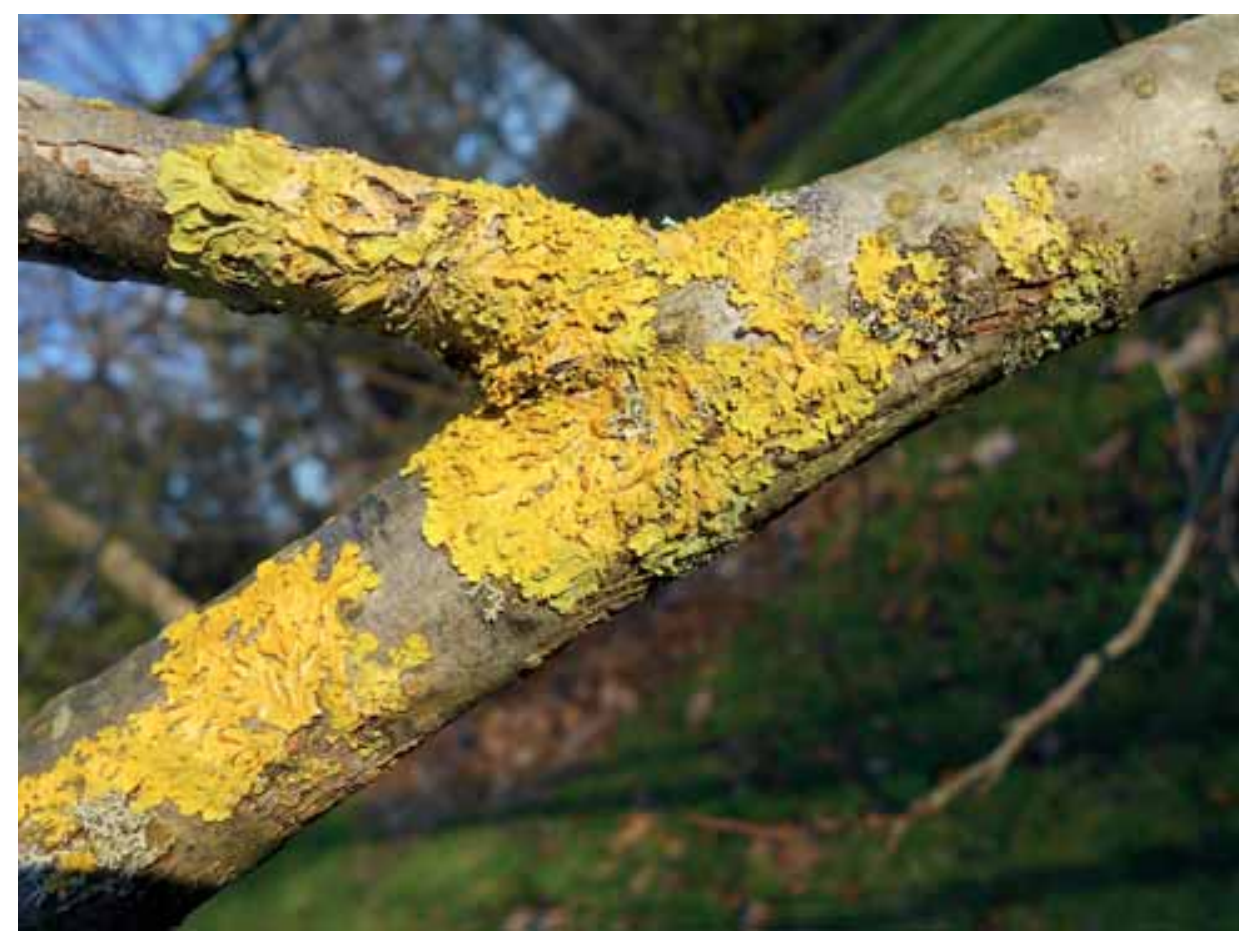

Fig. 2 Xanthoria parietina growing on Tapiscia sinensis. More information on lichens can be found in the "Lichens in the Garden" leaflet, a short guide to some lichens at the Edinburgh Garden. Photo: Tony Garn.

\section{February}

The nights are drawing out and carpets of snowdrops welcome spring. The slight but appreciable rise in temperature is always welcome.

Latua pubiflora (Fig. 3) is not to be missed as it is possibly one of the best plants to come out of recent plant-collecting expeditions to Chile. This introduction is from the joint University of Chile and RBGE expedition of 1998. It was noted as an unprepossessing plant with yellow fruit found growing as a spiny shrub to $2.5 \mathrm{~m}$ in alluvial gravel deposits on the eastern bank of the Río Quihue in the Los Lagos region of coastal mountains within southern Chile at an altitude of $140 \mathrm{~m}$ on a sparsely vegetated river bank. It is called 'El Loco' (the mad one) as it is highly toxic when ingested, as are many other members of the Solanaceae.

The flower buds open and appear from the dormant growth buds, expanding to $40 \mathrm{~mm}$ into tubular corollas with a five-pointed splayed end beyond which the extended stigma protrudes. The buds are encased by dark purple sepals which are forced open by the extending bright purple corolla tube. Hidden within are the five anthers held on filaments, the base of which are covered in fine white hairs. For a detailed description of the plant see Gardner \& Knees (2000). 
In the nursery at RBGE it reaches $4 \mathrm{~m}$ and is a very healthy, strong-growing deciduous shrub. As the girth of the main stem increases, the bark splits revealing fissures, dark green and brown in colour. The spines are prominent and extremely vicious! The growth can be managed by cutting back to ground level after flowering in April. This will give rise to the prolific production of watershoots from the pruning cuts. If this is done every six years the plant will remain manageable. Our plant, now ten years old, has great vigour and a wide spreading head.

Young plants growing in a nursery bed can languish for several seasons then vigorous shoots will sprout from the base of the plant and reach $1.3 \mathrm{~m}$ during the course of a single growing season. Could this be the hedging plant of the 21 st century: reliably floriferous, barbed to repel and responding positively to pruning cuts?

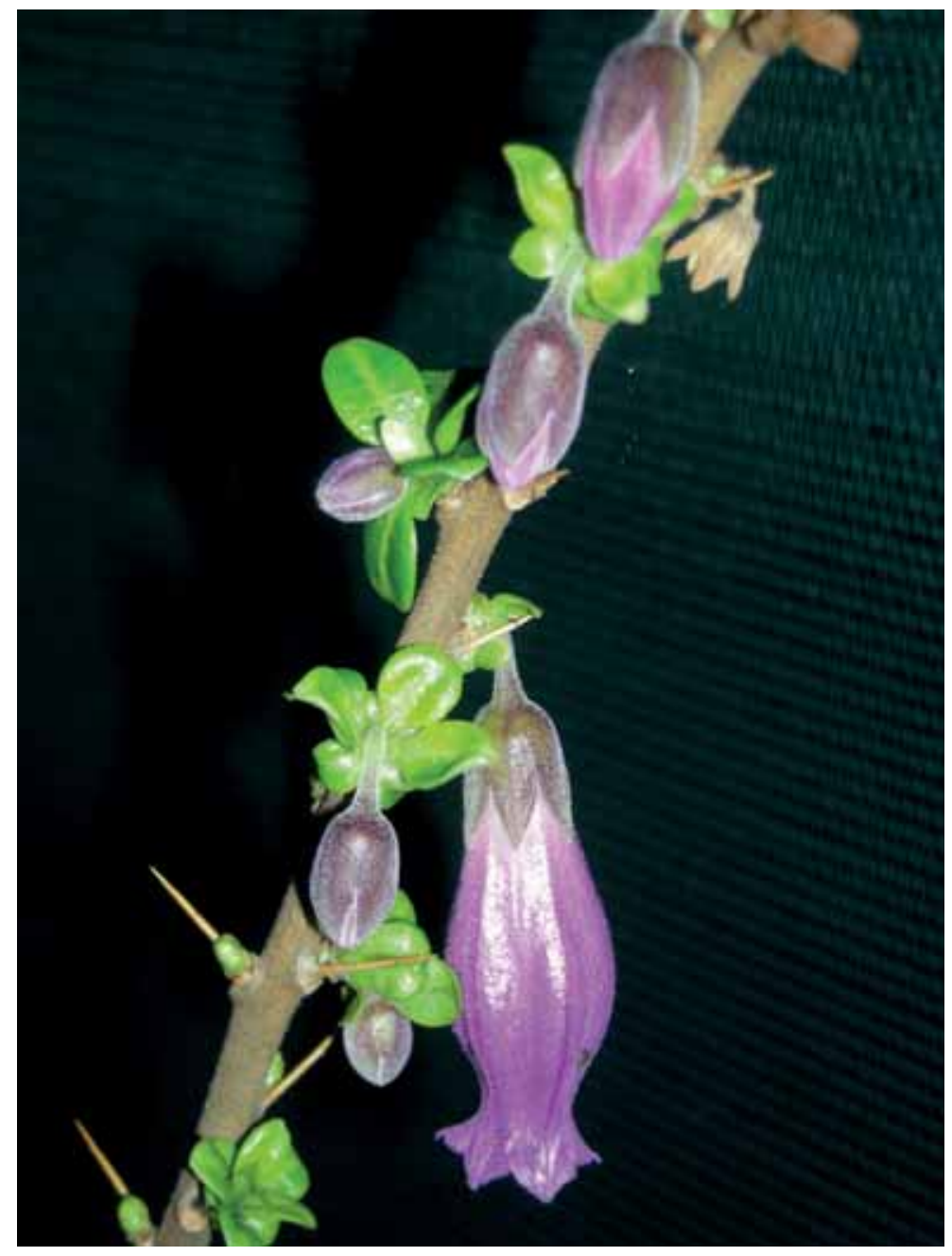

Fig. 3 Latua pubiflora $19980518 \mathrm{H}$ 1UCEXC. An unusual endemic native to Chile, uncommon in cultivation. Photo: Tony Garn. 
March

Swathes of yellow brighten our gardens as the daffodils flower. Early to leaf out, Sorbus caloneura (Fig. 4) is at its best as the winter buds burst and the fresh foliage expands. This wide-branched small tree has deeply veined foliage which appears bronze-brown from a distance; on closer inspection, however, red shades are more in evidence. Towards the tip, the leaves are serrated. As maturity approaches the colour turns to green and the tree merges into the landscape. Enjoy this plant at an early stage of foliage development.

Held within the expanding vegetation are the flowers cupped by the expanding leaves. The buds soon develop and a mass of individual small white flowers make up the inflorescence. It is a native of Hubei Province in China where it grows as part of the forest cover in mountain regions at $600-1,200 \mathrm{~m}$.

Fig. 4 Sorbus caloneura 19810837A SABE 753. One of the first deciduous trees to leaf out, with deeply veined foliage. Photo: Tony Garn.

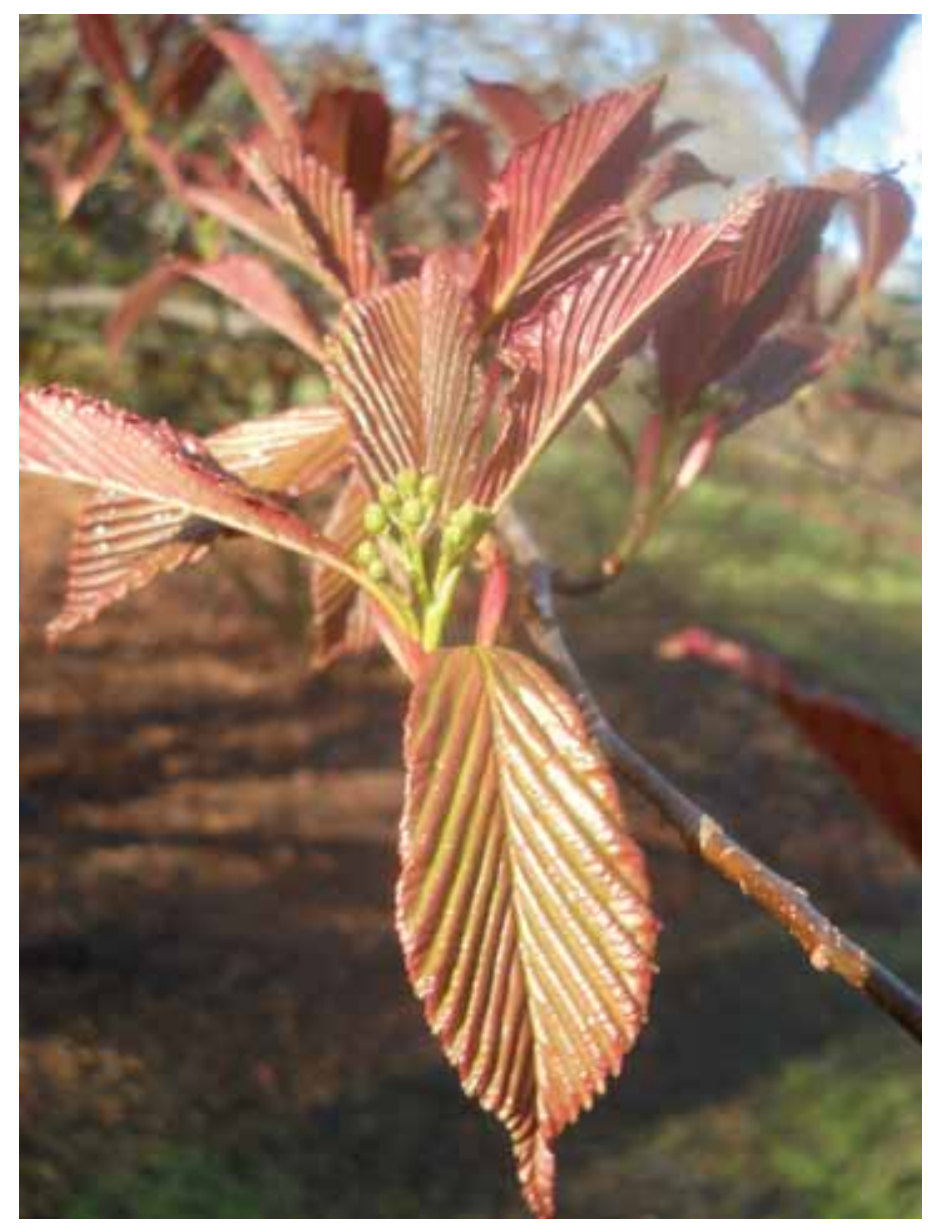




\section{April}

The lawns are striped to perfection. The tree canopies are leafing out and better weather heralds the start of meals enjoyed al fresco. Lawns are an underappreciated asset in the Garden as they give a feeling of space and openness, acting as a foil to the plant collection, allowing access through the garden and providing an important place of rest. Lawns also absorb water. This is increasingly important with the steady march of hard surfaces that shed rainfall from torrential rainstorms to exacerbate the localised flooding our changing climate brings. The soft surface of lawns also absorbs noise; hard surfaces tend to bounce noise around, creating another onslaught to our senses that is increasingly detrimental to our quality of life. A well-mown sward is a joy to see.

On the Pyrus lawn in the south-west corner of the Garden is Pyrus korshinskyi (Fig. 5). Registered in the Tree Register of the British Isles as a 'Champion Tree' for both girth and height, it was last measured in 2004 and recorded as being $8 \mathrm{~m}$ in height with a trunk girth of $1.26 \mathrm{~m}$. This is one of many specimens to be given champion status in the Living Collection at the Edinburgh Garden.

The ornamental pears are truly magnificent in blossom and this is an excellent specimen. It is a deciduous tree that produces lovely fresh green leaves, but they are overwhelmed by the profusion of blossom terminating the shoots. The leaf petiole is tinged

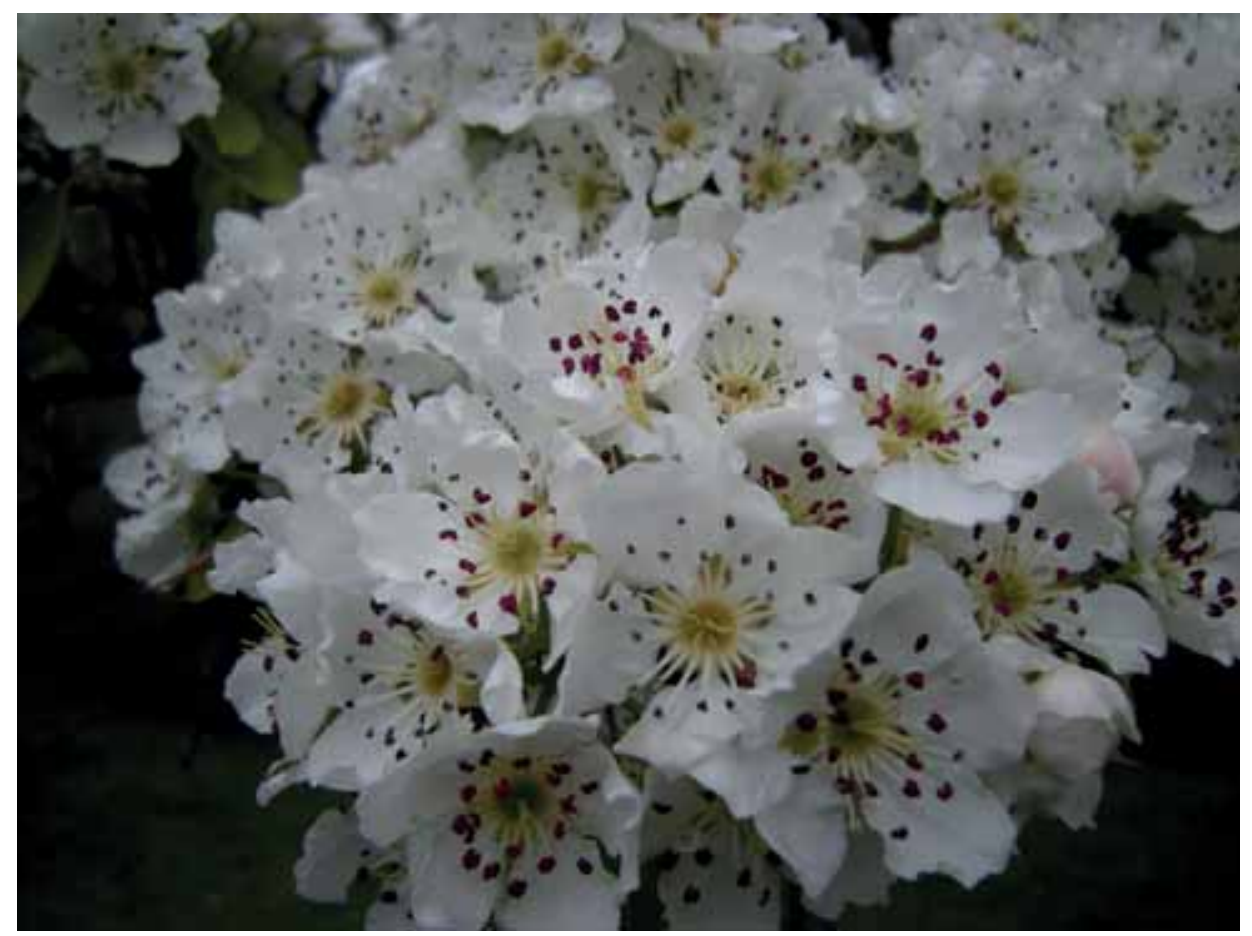

Fig. 5 Pyrus korshinskyi 19698779A. Needing space to develop into a mature specimen, this broadcanopied tree is worth the investment in planting and cultivating. Photo: Tony Garn. 
red matching in with the tight bud colour. As development continues the five petals become pure white, contrasting with the vermilion-red anthers. In the centre of the flower is the split stigma, three pin-like points triangulating away from each other. The bark is deeply and attractively fissured from the trunk into the mature and extensive branch framework.

May

Magnolia, Rhododendron and Meconopsis: who could choose a better winning combination in the month of May? So much colour originating from so many different countries. May is the month when the plant collectors' legacy really is appreciated. The introductions from the Himalayan region are particularly worthy of mention.

A walk through the garden will prove rewarding with so many rhododendrons in flower. In the copse $R$. orbiculare ssp. orbiculare and $R$. vernicosum are full of colour. Both are native to western China where the seed was collected. Following sowing, germination and growing on we now appreciate the full beauty of these wide-spreading evergreen shrubs.

The truss of blooms on Rhododendron sinofalconeri (Fig. 6) is worthy of show merit. The colour and form are first class. Give this 16-year-old plant time to mature

Fig. 6 Rhododendron sinofalconeri 19960615 A KYE AC1213. The best of the bigleaved rhododendrons. Photo: Tony Garn.

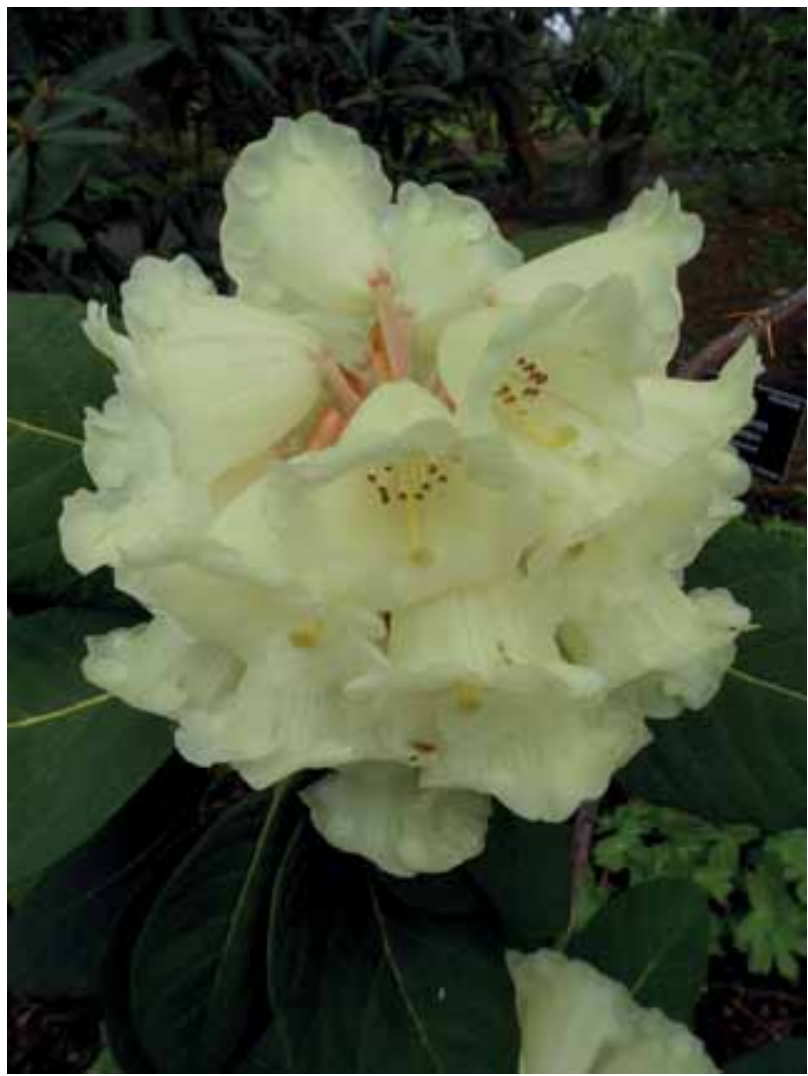


and it will equal the best of the rhododendrons collected by the most renowned of plant collectors through the past century. Thirty and more individual flowers the colour of rich cream cow's milk group together as the terminal inflorescence. This is a relatively recent introduction (1995 Kunming/Yunnan Expedition) from the south-facing slopes of the mountains south of Kunming, China in an area near Wenshan at c. $2,550 \mathrm{~m}$. At the Edinburgh Garden it revels in a cool, moist climate where it grows in mixed scrub, making a small tree that reaches $4 \mathrm{~m}$. Our plant was collected at the maximum extent of the altitudinal range according to the Flora of China (2017) which gives the distribution range as Southern Yunnan Province into Vietnam at 1,600-2,500m.

June

Midsummer colour is provided by a wealth of genera: woody, herbaceous and annual. Walk through the garden during this month to appreciate the heady fragrance emitted by the many species of Philadephus known as mock orange. Philadelphus schrenkii (Fig. 7) was an ideal choice to add to the Collection. Growing in the nursery was a

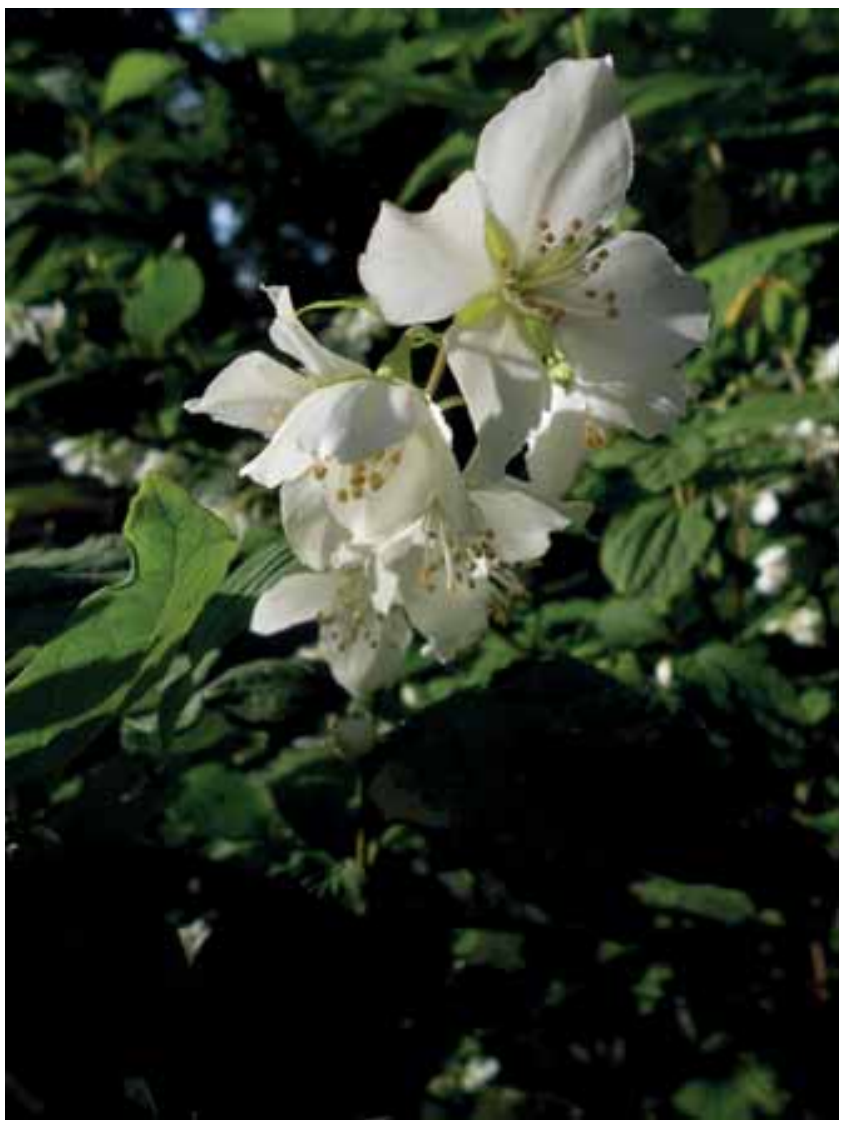

Fig. 7 Philadelphus schrenkii 20051990S BBJMT 115. One of the finest scents pervading through a summer garden. Photo: Tony Garn. 
selection of recently potted woody species collected in 2005 during a collecting trip to Japan. Developing to a huge deciduous shrub, $4 \mathrm{~m}$ in height $\times 2 \mathrm{~m}$ in breadth, the mother plant from which seed was collected to raise these nursery plants had reached these dimensions growing in dry stony loam on a steep south-east facing mountainside in dense mixed woodland in Niigata Prefecture, Japan. The month of June sees it covered in flowers, white petals and prominent anthers making up the multi-flowered racemes. These exude a delicious fragrance. In the wild companion plants include Lindera sp., Corylus sieboldiana, Philadelphus satsumi and Cephalotaxus harringtoniana.

\section{July}

Plantings are lush and well grown, and herbaceous plants make a colourful display. A late flowering display of iris is always welcome and Iris ensata var. spontanea (Fig. 8) in the Biodiversity Garden fulfils this task admirably. Collected in Japan in 2007, this wild-occurring variety of I. ensata was found on flat open grassland at 1,075m, associating with species of Scabiosa, Miscanthus and Hemerocallis. With tight upright leafy

Fig. 8 Iris ensata var. spontanea 20071466B BCJMM 178 . Best grown as a mass planting to maximise the effect during flowering. Photo: Tony Garn.

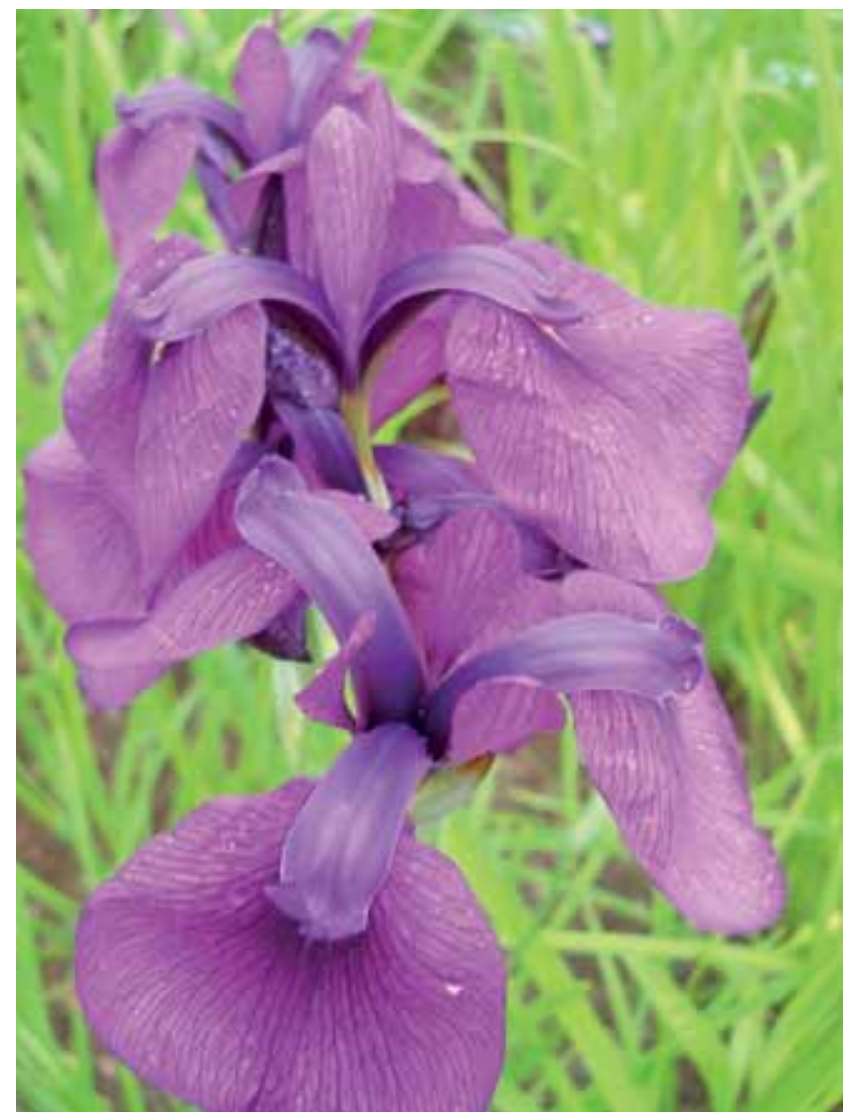


spears of growth, this herbaceous perennial deserves a place in the border as it has bright purple flowers and a delicate yellow stripe on the falls. Looking through the clump, colour variation is evident which is consistent with progeny arising from wild collected seed. Plant it at pond margins or in moisture-retentive soil where it will reach an ultimate height of $1.2 \mathrm{~m}$. Numerous cultivars have been raised, many in Japan and latterly in the West; most are characterised by large petals and a flat profile over the top of the flower. Several cultivars are grown at Edinburgh as well as the species.

\section{August}

Quite often during this month we experience the summer monsoon with periods of sudden intense heavy rainfall. This is a relatively new weather event and may be related to our changing climate.

RBGE has several collections of Koelreuteria paniculata (Fig. 9). One, growing in the Copse, flowers profusely and was collected by Joseph Rock in 1926. In his notes he

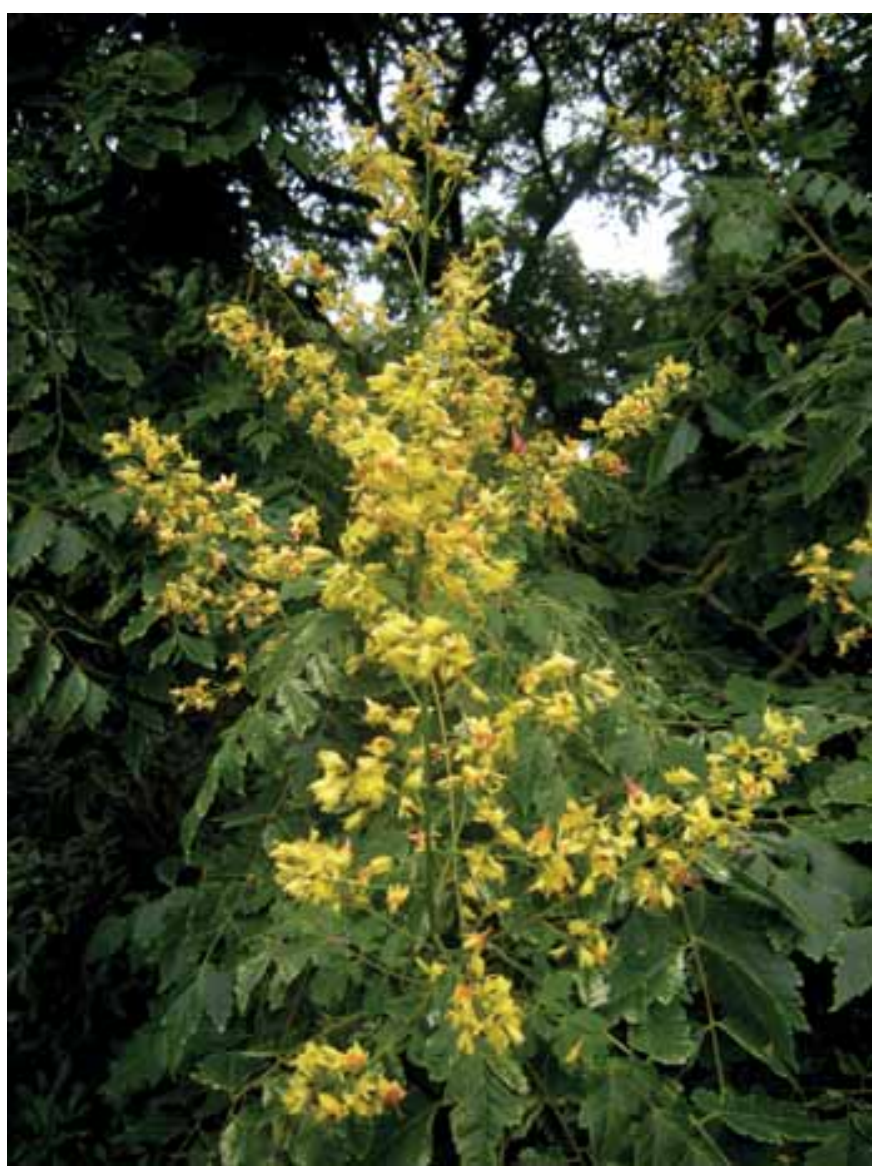

Fig. 9 Koelreuteria paniculata $19687722 \mathrm{~A}$ Rock 14994. Deciduous tree bearing panicles of yellow flowers; red, inflated seed pods follow. Photo: Tony Garn. 
mentions that at $12 \mathrm{~m}$ it was the tallest tree in the village of Nyiba, Gansu Province, China. Rock saw it here growing in the drier regions of a river bank (Bean, 1976). Other collections were made on the west coast of the Republic of Korea at sea level; Honshu Province, Japan from a group of naturalised shrubs, again at sea level; and Sichuan Province, China, in a south-facing dry valley bottom at $2,070 \mathrm{~m}$. The tree is covered in panicles (hence the specific epithet) of individual yellow flowers. As the flowers fade and fall the seed pods develop. Initially they are a swollen red triangular shape but progressively they balloon into a conical shape. An added bonus is the good autumn colour from the deciduous foliage.

\section{September}

A colour change in herbaceous leaves and deciduous trees under stress can now be perceived. In the sheltered border within the enclosed area between the Tropical Palm House and the Orchid House there is a heavy scent given off by the mass flowering of Myrceugenia leptospermoides (Fig. 10). This scent is reminiscent of a good honey, and the pollinating insects are drawn to it in their droves. Prolific white bloom covers the

Fig. 10 Myrceugenia leptospermoides $19891714 \mathrm{C}$ Gardner 3639. Making the most of a favourable microclimate. Photo: Tony Garn.

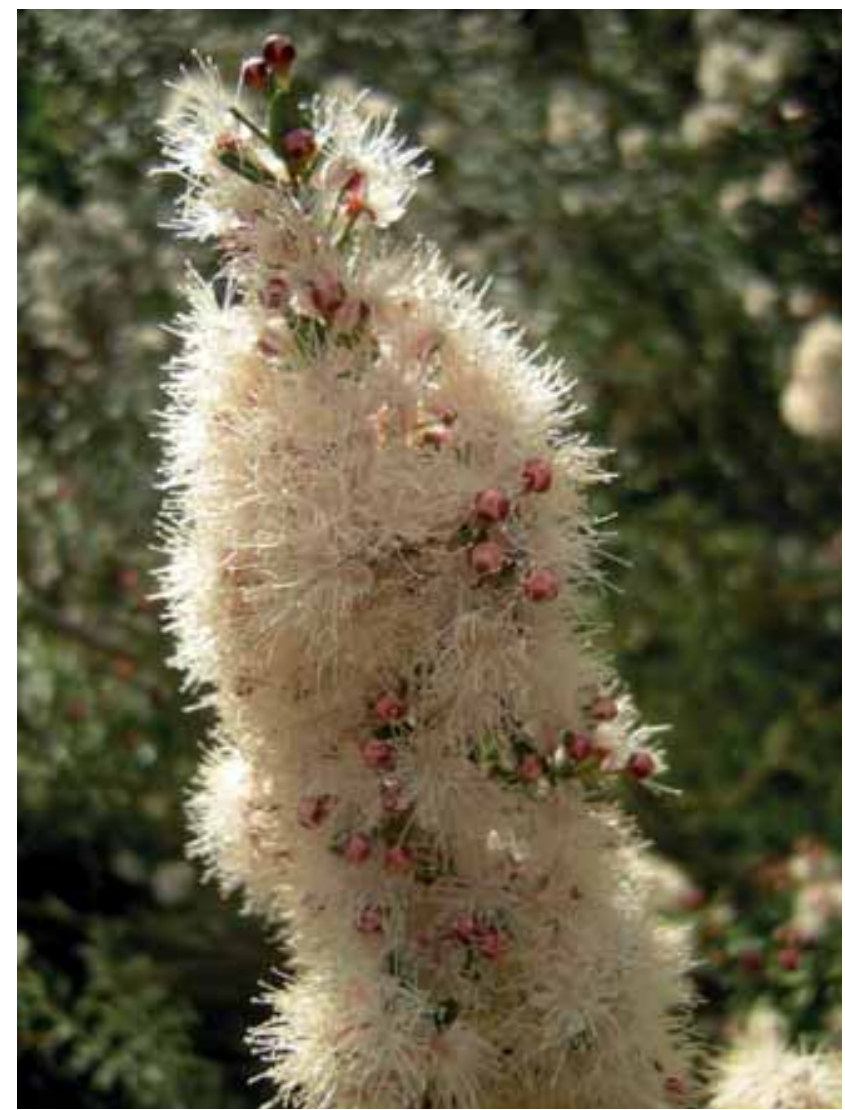


terminal growth of the current year's wood. This mass of flower parts bursts out of small pink buds. On the growth below are the fruits, a proliferation of red to black, a memory of previous successful flowering seasons. Self-sown seedlings can be found in the soil beneath the canopy. It is an evergreen, multi-stemmed shrub from Chile where it is found in coastal areas in the central region of the country.

\section{October}

The autumn colour of the trees is best during the second part of the month; temperatures drop and the deciduous foliage changes colour. The deep red of Euonymus alatus and Liquidambar acalycina make them two exceptional woody genera for autumn.

Within the Montane Tropics glasshouse are several rhododendrons of subsection Vireya. Rhododendron konori (Fig. 11), a variable species, is native to the highlands of Papua New Guinea. The large, pure white flowers exude a powerful deep scent. Many collections have been made by successive staff of RBGE and introduced through the Forest Research Centre at Lae in Papua New Guinea. It is the parent of many popular hybrids. In Australia and USA where vireyas are hardy outdoors, a lot of hybridisation

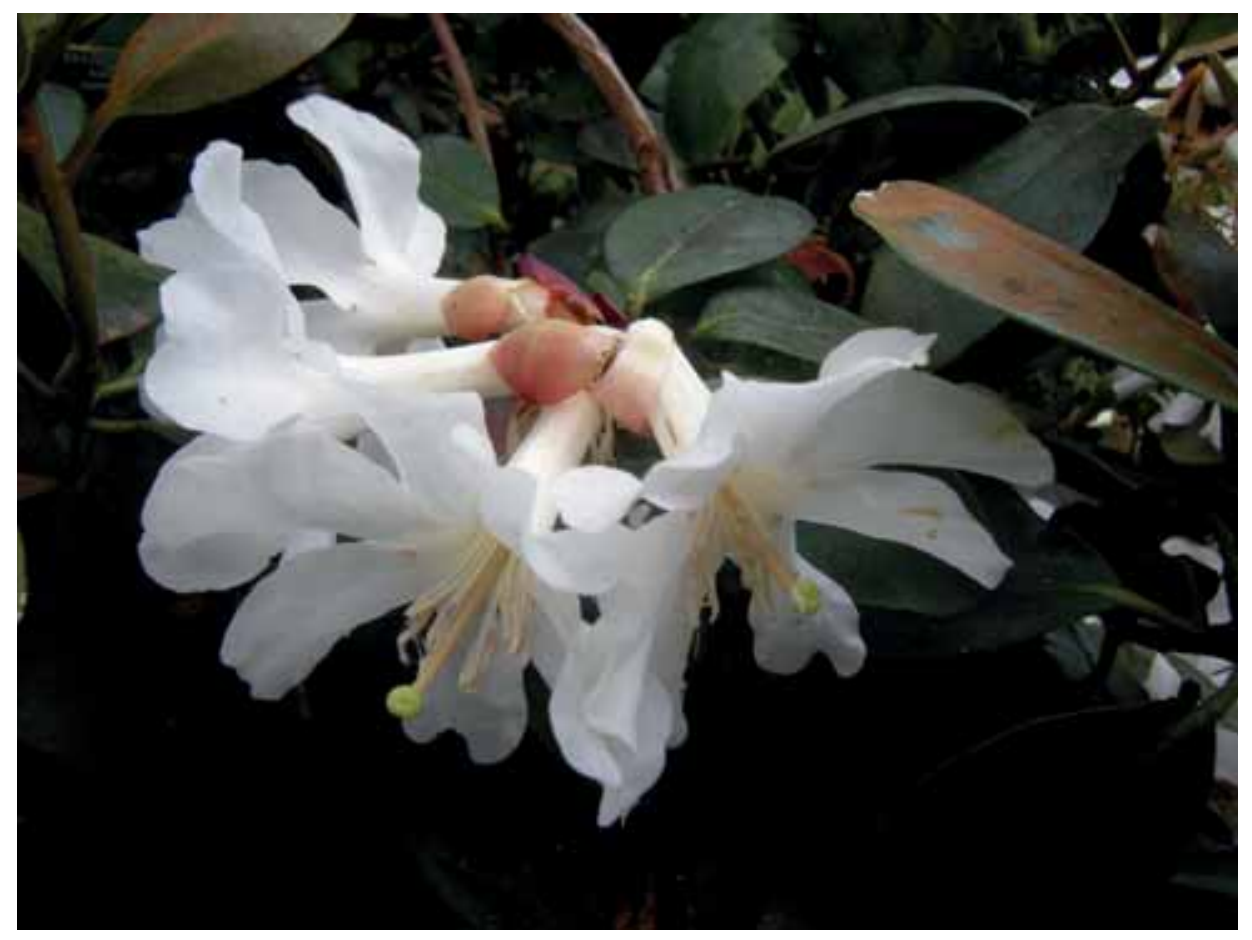

Fig. 11 Rhododendron konori 19731630 Lae 37954. One of the c. 300 species of Rhododendron subgenus Vireya, thriving in frost-free protected cultivation and absorbing the long daylight hours of a Scottish summer at RBGE. Photo: Tony Garn. 


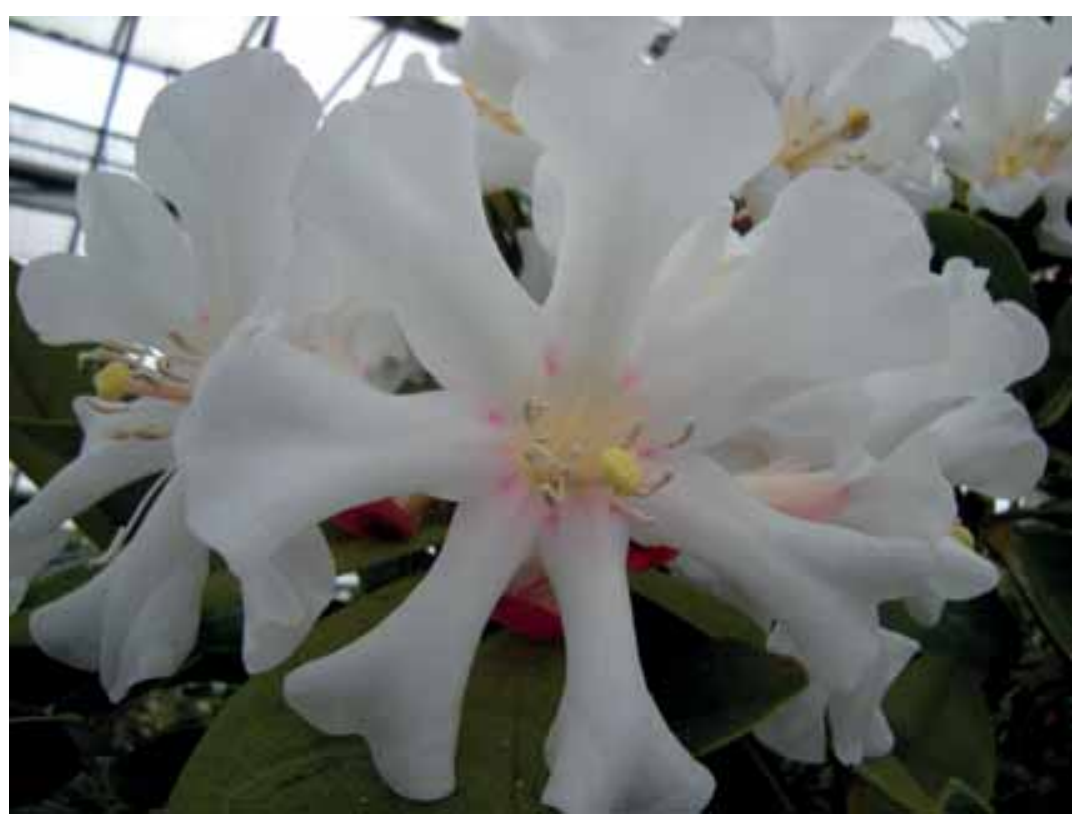

Fig. 12 Rhododendron leucogigas 'Hunstein's Secret' $\times$ konori 19880110. A hybrid Vireya rhododendron showing traits of flower colour and shape of both parents. Photo: Tony Garn.

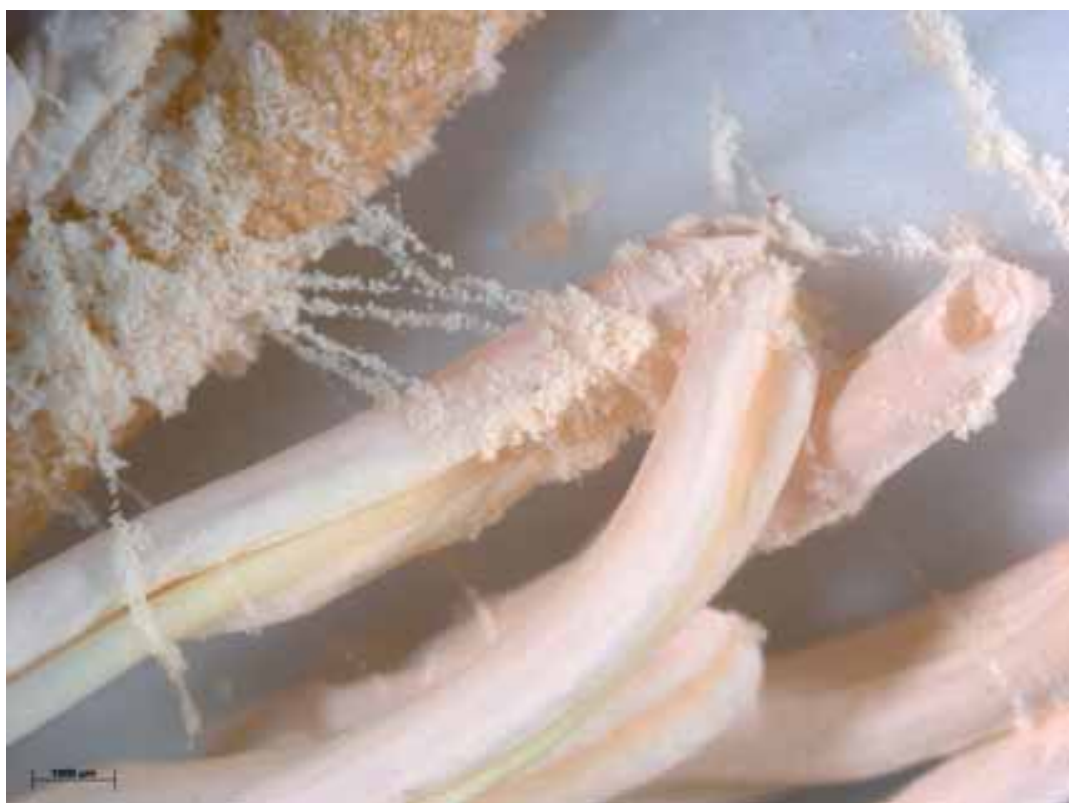

Fig. 13 Rhododendron konori 19731630 Lae 37954. Anther tubes and pollen grains. The image was taken on a Carl Zeiss Stemi 2000C stereo dissector microscope and the scale bar is 1,000 microns = 1mm: Image: Frieda Christie. 
work has been carried out on these species. One such is Rh. leucogigas 'Hunstein's Secret' $\times$ Rh. konori (Fig. 12). This has distinct pink markings at the base of each petal. On opening there is a pink tinge to the corolla which fades as it matures.

In full bloom the pollen grains hang from the anthers as a stringy dry powder. These anthers are on long, slightly curved filaments which push the pollen strands towards the edge of the petals. This ensures a greater 'hit' by the pollinating insects which are attracted by the overpowering perfume. I took two flowers to the Scanning Electron Microsope Suite in the herbarium building late one afternoon and by the following morning the perfume had filled the whole corridor. The pearl-like strands of pollen grains can be seen in Fig. 13.

\section{November}

The structure and silhouette of mature deciduous trees lit through by the low angle of the sun as it rises and sets is worthy of mention. November means the tail end of the autumn colour, foliage fading and the need for dormancy.

Catch the canopy of Sorbus alnifolia (Fig. 14) with the low sun and you will understand why Reginald Farrer grabbed a handful of berries and returned with the seed from

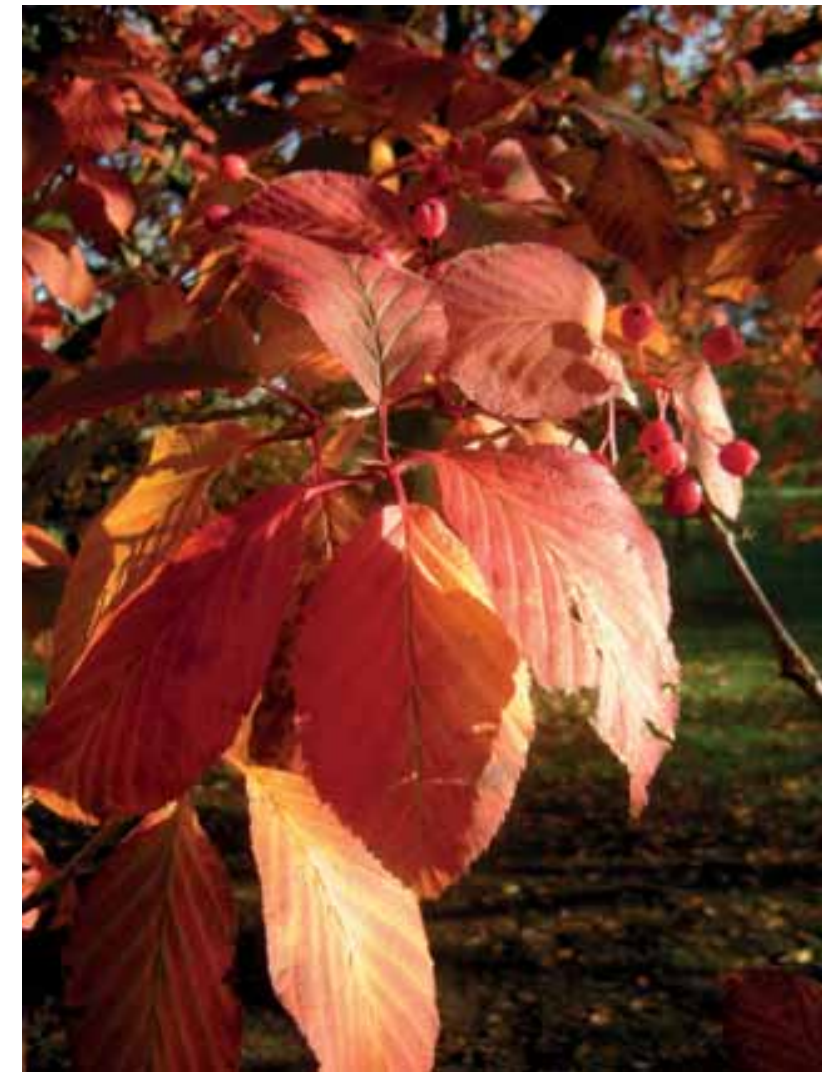

Fig. 14 Sorbus alnifolia 19150093A Farrer 338, one of Farrer's finest introductions. The genus Sorbus is known for autumn colour. Photo: Tony Garn. 
Gansu Province, China on his first major expedition. This plant is well worth growing for the russet browns and deep reds of autumn colour. The leaves are deeply veined and this prominent venation is enhanced with the seasonal colours. It is a slow-growing species, eventually reaching $7 \mathrm{~m}$ tall, with an equal canopy width. Additionally, there is a prolific crop of berries throughout the tree. As yet the pigeons have not started their acrobatics of gaining a toehold and eating as their weight and wing momentum allows on the flexible twigs.

\section{December}

Season's end and, with a view to the future, the new planting commences. The mahonias have shiny evergreen foliage and terminal panicles of yellow flowers. Mahonia napaulensis (Figs 15 \& 16) was collected in Nepal on a ridge north of Kumatoang and was growing within Quercus and Rhododendron forest at 2,780m. Our plant in the herbarium

Fig. 15 Mahonia napaulensis 19922354 Long \& McDermott 21983. The flower truss provides welcome winter colour and scent. Photo: Tony Garn.

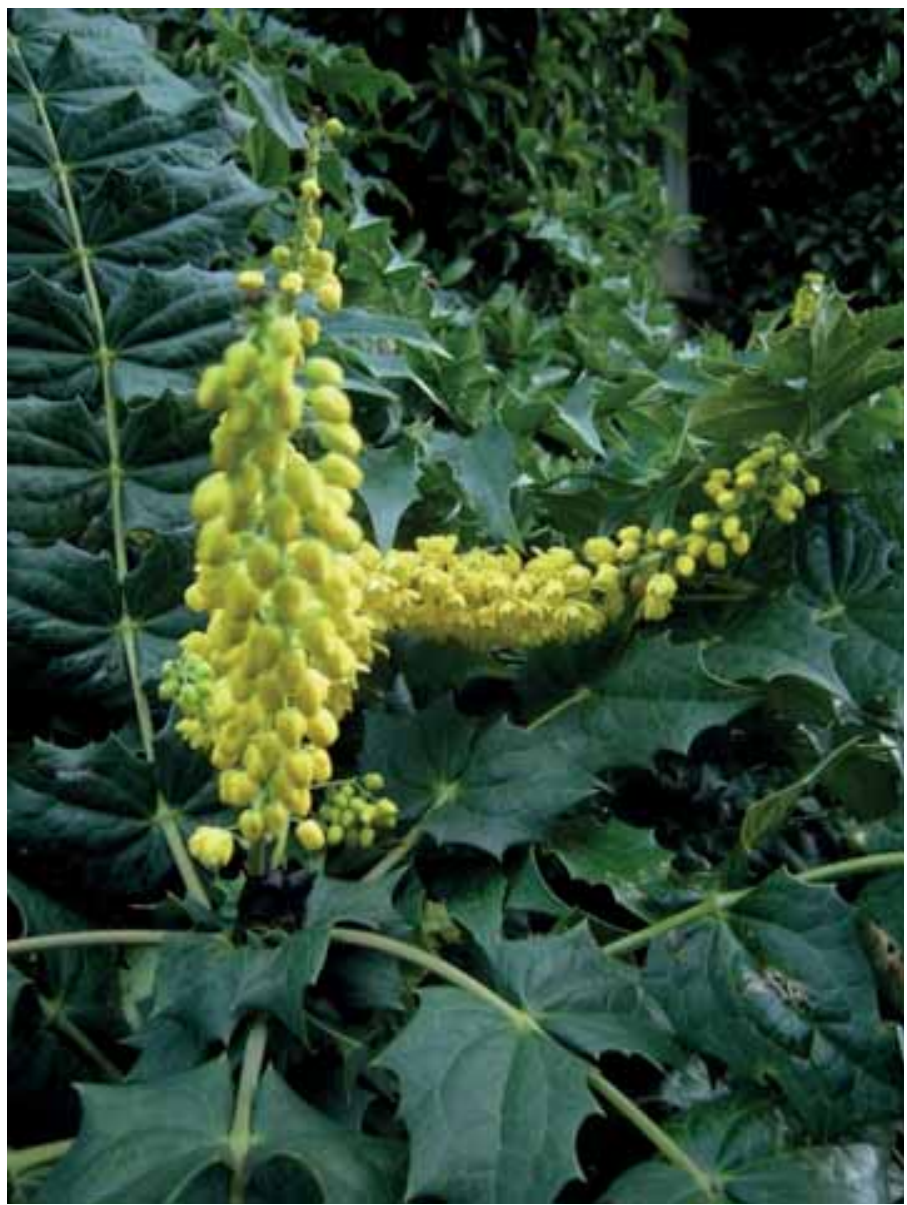




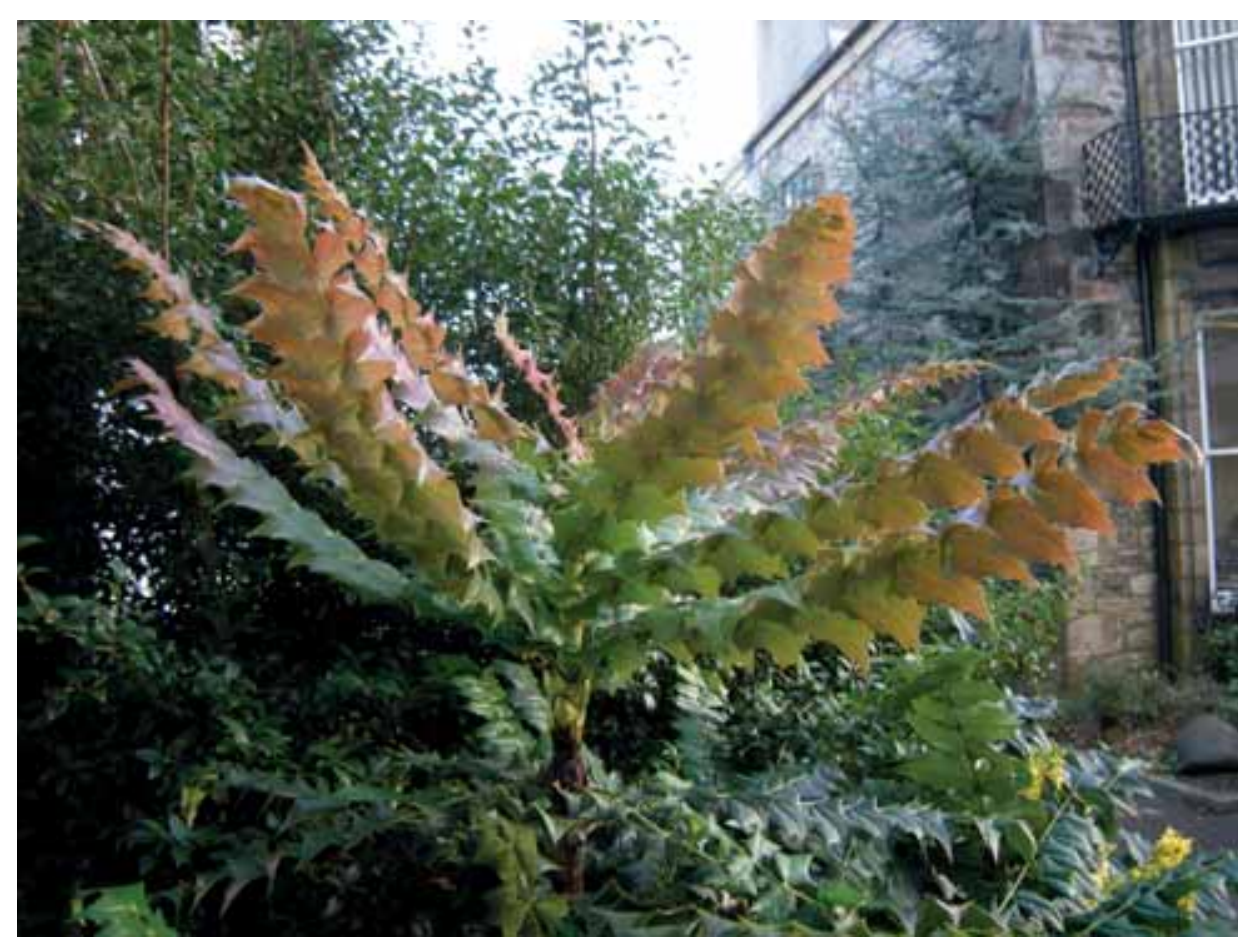

Fig. 16 Mahonia napaulensis 19922354 Long \& McDermott 21983. This image illustrates the bronze foliage flush in spring. The Living Collection at RBGE is used by many including visitors, students from many academic disciplines and the international scientific community. Some appreciate the botanical details, others the decorative or growth characteristics that make plants suitable for specific garden or landscape uses. Photo: Tony Garn.

car park has sprouted late-extension growth. The leaves are just turning green from the juvenile bronze. When mature there is a blue tint to the foliage. Several racemes extend from the terminal bud and are composed of individual bright yellow flowers, most welcome in this season of low daylight hours. The delicate scent from these flowers is an added bonus.

In a frosty spell the tips of these leaflets have turned black and survival to maturity may be doubtful. There is, however, a mature plant growing in the vicinity of Inverleith House and here it is protected from the damaging effect of frost by the canopy of taller trees. This is a prime example of site, situation and microclimate all conspiring to make the diversity of our plant collection so interesting.

\section{THREATS TO LIVING COLLECTIONS}

Based on observations and experience gained from my life in botanic garden horticulture, I have listed eight areas of concern which I believe threaten living collections in botanic and other gardens. 


\section{A changing climate}

This is a given: the climate has always changed (Bindoff et al., 2013) and plants have adapted, but the speed of change now is unprecedented. The natural environment continually changes and vegetation slowly migrates where opportunity for colonisation is presented (Huntley et al., 2017). A climax vegetation develops, matures and senesces, but this is only possible with gradual change. A cultivated flora is different as it is composed of many plants that originate in countries with different climatic conditions from our own, and plants are held as collections in one place and have no option for migration. Where a changing climate presents environmental challenges it may lead to weakened growth, dieback, infestations by pests and diseases, and ultimately death. These plants are then lost to cultivation. However it can also offer opportunities to try hitherto difficult species to cultivate. Due to the financial cost of mounting collecting expeditions and the fact that some areas of the world are now politically inaccessible, many species are not replaceable in the cultivated landscape. A loss to botanical collections is also a loss to science, amenity and the horticultural profession (Martin, 2014).

\section{Perception that the living collection will perpetuate ad infinitum}

In a changing world with many variables such as financial and political upheavals, nothing is forever, changes occur and organisations fail. In previous years RBGE has been the recipient of both living and preserved plant collections. These have been donated by individuals or organisations some of which have changed or closed, meaning that they have been unable to perpetuate their collection or supply material to other collections and institutions.

\section{The introduction and spread of pests and diseases}

Increasingly we read of new threats to plant life caused by novel pests and diseases. Previously thought of as exotic, these pests are colonising northwards of their accepted distribution range as the climate makes their survival and breeding possible (DEFRA, 2014). In recent years RBGE has lost mature specimens to previously unrecorded diseases. The threat is no longer just on paper and in scholarly articles, it is here in the soil and on the foliage.

\section{A lack of succession planning}

This refers to an appreciation of the skill of the propagator. As plants grow they can reach a stage where rejuvenation is necessary. The question is: are the skills and the horticultural infrastructure present to produce a future generation of young plants? Can the Garden develop rather than accepting moribund plantings? Succession planning is required not only for the plants but also the skilled staff to grow them. As the workforce 
ages, lifelong skills including both local and institutional knowledge are in danger of being lost (see below). A well-planned succession of staff will ensure this knowledge is not lost. Of greater interest are the prophecies of business leaders that the labour market is to reduce and robots take on more work as artificial intelligence is harnessed by multinational corporations (Larson, 2017). As a result, the caring, creative and supervisory professions may be the only ones to survive.

\section{The economy}

Most botanical collections in Britain are funded by the public purse. If the economy weakens so too will tax revenues which provide these funds. Botanic gardens have already felt the economic bite through the reduction in staff and resources. Where this occurs the choice plants will be the first to suffer as they are often the ones that require the most care and maintenance. A plantsman with knowledge of the collection can prevent rampant growth of vigorous plants from swamping and suffocating the choice species. If there are insufficient knowledgeable plantsmen due to a lack of funding, this ability is lost. Here the networks that connect botanic gardens come into their own. For instance, threatened species can be moved between gardens to benefit their survival. As long as they have plant passports and full collection data it is possible to move them and thus ensure that the parent garden can re-access living material at a future date.

\section{A deskilled workforce}

Mechanisation and technology enable a garden to be run with fewer and fewer staff. In the majority of organisations it is the wage bill that consumes the largest slice of the budget; however, increasing use of machinery creates distance between the plant collection and staff. More time is spent on tasks such as blowing leaves from roads and paths to ensure public safety. Spending less time engaging in traditional horticultural skills will slowly erode the dexterity with which plants are maintained and the ability to remember the process or details. Gradually little snippets of the trade are consigned to history. It is like a leaking water butt - suddenly, in a dry spell, when the water is needed, it is a surprise to discover there is no water. Where traditional horticultural skills are used there is closeness to the living plant. Characteristics, health, growth rate and suitability to the planting site are noticed. In essence, a plantsman will have an innate awareness of the collection. Blowing leaves, rather than raking, strimming rather than using hand shears, takes away from this intimacy and the pace to observe. There is already a robotic mower that will cut the lawns while you sleep. A weeding machine for commercial crop applications is available (Wane et al., 2017). How long will it be before similar technology reaches the amenity market? It should not be too difficult for an engineering solution to allow the Beech Hedge at RBGE to be cut remotely. This year it is $8 \mathrm{~m}$ high and $212 \mathrm{~m}$ long and takes two staff members six days to complete the annual trim. These advances do have major health benefits: for example, the debilitating risk from noise and vibration 
suffered by long-term users of such machinery is reduced. The task becomes safer and there are fewer opportunities for life-changing injuries to occur. What is required are enclaves of traditional horticulture. When the need arises to manage the collection there should be somewhere to go to retrain. As part of the Diploma in Herbology course at RBGE the tutor asks each student to conduct and record an interview with someone who remembers using traditional remedies. These people are becoming more difficult to find as most are in their $80 \mathrm{~s}$ and 90 s. These people used tinctures and poultices before inoculations and the advent of the NHS. The parallel with the loss of skills and traditions in horticulture can be seen here. For nigh on 50 years mainstream medicine has been used in place of natural remedies. There is now a resurgence of interest in the traditional ways of treating illness. The difficulty is finding those with the skills of old.

\section{Diversification}

There is a need to develop income streams to offset the cost of maintaining the plant collection and the Garden. This becomes a challenge because often the infrastructure within a garden is not suitable for the type of events that will generate sizeable income. With events come a convoy of white vans with drivers who are always constrained by time at the wheel. It does not take long for lawn edges to be ruined and double parking to become the norm, causing the edges of the garden infrastructure to gradually erode. Money that was budgeted for reinstatement does not materialise as the predicted income from the event falls short of the profit the organisers forecast. The garden slowly loses its manicured edge and becomes less attractive to visitors. Social media is now a powerful tool to praise or criticise, and organisations have to be mindful that these deteriorating aspects can lower the star rating. Poor reviews on social media result in a reduction of visitor numbers and a vicious downward spiral.

The other side of diversification is that a garden can become too popular. High numbers of visitors lead to erosion of lawns and soft landscape areas. Often this is first noticed with the flowering of a plant that has a good scent. At RBGE the majestic Magnolia campbellii 'Charles Raffill' draws visitors to its trunk (Fig. 17). This creates a pinch point and compaction over the root plate. Visitors are keen to get close and observe it. This plant is in the centre of a cultivated area. A tramped path, widening each day, is soon created. Vegetation is trampled underfoot and compaction adds to the long-term damage. In some situations plants are lost to foot traffic.

\section{Decision makers with no product knowledge}

Traditionally, company managers came up through the ranks having spent time on the shop floor. This equipped individuals with a thorough grounding in product knowledge and an understanding of the tasks and routines that gave the product its reputation. Fresh eyes and new talent rejuvenate the Garden but just occasionally this can have a counterproductive effect. To ensure the continued success of the plant collection, Directors and 


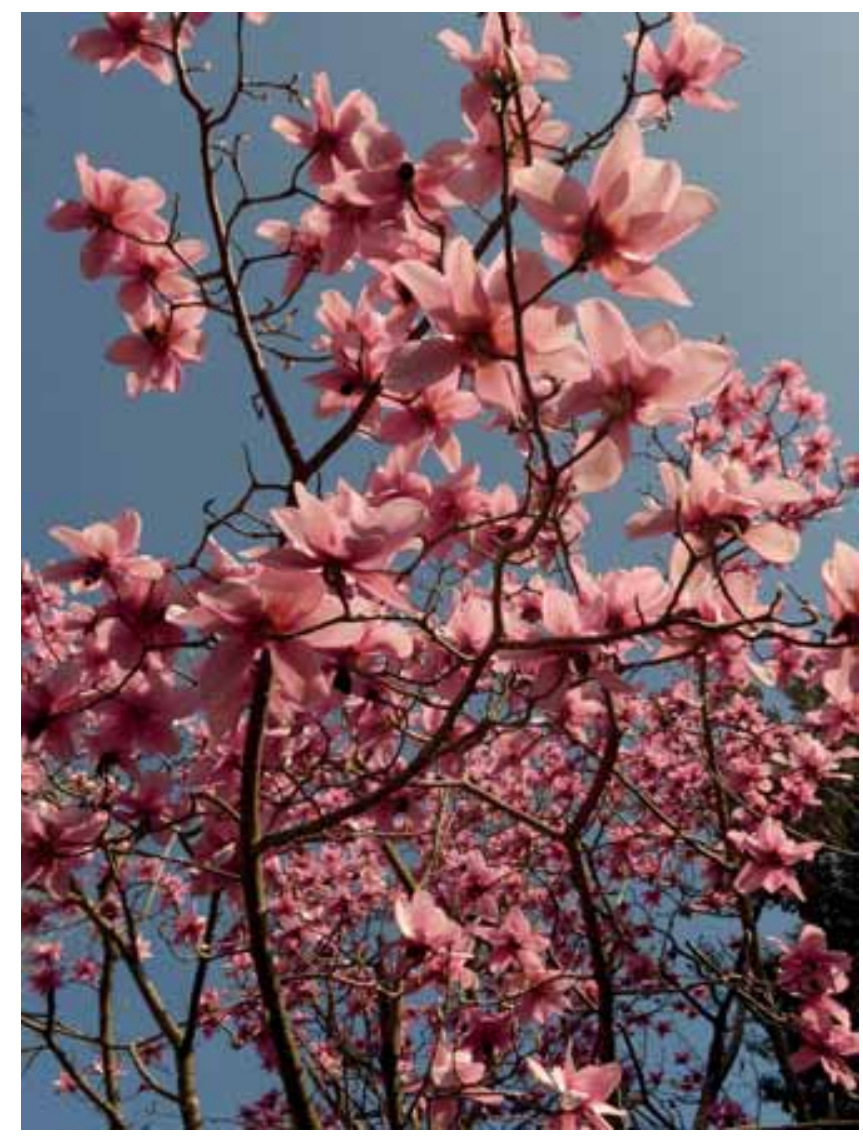

Fig. 17 Magnolia campbellii 'Charles Raffill' 19480317A. Photo: Tony Garn.

Curators need to engage with and support the Horticulturists and Scientists who are collecting, planting and cultivating. It is, after all, these front-line operations that our visitors appreciate.

\section{CONCLUSION}

With forward-looking individuals who are aware of the natural and cultivated world and careful management of horticultural skills by those responsible, I feel confident that the abovementioned threats can be overcome. It will take a change from the 'clipboard culture' and the policies and procedures of the early part of this century to ensure this happens, and the way forward will require hands roughened through working the soil. Technology, for example, the internet, will become increasingly important with initiatives such as the promotion of citizen science. These mass science-related initiatives and activities motivate people to become involved and although the computer is the portal the outdoor environment is the toolkit. As the years progress, then decades pass, 
each season brings fresh interest and it is, after all, the plants that make a garden. As custodians of gardens, repositories of plants, we must constantly strive to keep these collections alive through promotion of our values and propagation and care of our source material. We interact with plants daily, often subconsciously; they are there, part of the background, and we must remember to value them. Jon Ungoed-Thomas in The Times (2017) writes that "Newcastle is to use millions of pounds from its public health budget to help keep open its public parks as open spaces provide huge health benefits". This lateral thinking is a good result for horticulture. Professionally, plants are our currency, having a value far in excess of a sterling exchange rate. We must know them, grow them and always cherish them.

As horticulturists we can all make a difference to the success of the Living Collection wherever we work. We need to ensure that skills are passed on through the generations and that knowledge is not lost, and we must also retain the written word. This is easy in book or manuscript form, but the electronic version has a habit of being transient, yet contains equally, if not more, relevant information to pass on to future generations. Change is inevitable; how change is managed is pivotal to the continued well-being and development of the collection at RBGE and other gardens, both nationally and internationally.

\section{REFERENCES}

BEAN, W.J. (1976). Trees and Shrubs Hardy in the British Isles (8th edn). John Murray, London.

BINDOFF, N.L., STOTT, P.A., ACHUTARAO, K.M., ALLEN, M.R., GILLETT, N., GUTZLER, D., HANSINGO, K., HEGERL, G., HU, Y., JAIN, S., MOKHOV, I.I., OVERLAND, J., PERLWITZ, J., SEBBARI, R. \& ZHANG, X. (2013). Detection and attribution of climate change: from global to regional. In: STOCKER, T.F., QIN, D., PLATTNER, G.K., TIGNOR, M., ALLEN, S.K., BOSCHUNG, J., NAUELS, A., XIA, Y., BEX, V. \& MIDGLEY, P.M. (eds), Climate Change 2013: The Physical Science Basis. Contribution of Working Group I to the Fifth Assessment Report of the Intergovernmental Panel on Climate Change. Cambridge and New York, Cambridge University Press, p. 894.

DEFRA (2014). Protecting plant health. A plant biosecurity strategy for Great Britain. Available online: www.gov.uk/government/uploads/system/uploads/attachment_data/file/307355/ pb14168-plant-health-strategy.pdf (accessed June 2017).

FLORA OF CHINA (2017). Available online: www.eFloras.org (accessed July 2017).

GARDNER, M. \& KNEES, S. (2000). Latua pubiflora: a beautiful winter flowering shrub with an evil reputation! The New Plantsman, 7(3), 184-190.

HUNTLEY, B., ALLEN, J.R.M., BENNIE, J., COLLINGHAM, Y.C., MILLER, P.A. \& SUGGITT, A.J. (2017). Climatic disequilibrium threatens conservation priority forests. Conservation Letters. Available online: http://onlinelibrary.wiley.com/doi/10.1111/ conl.12349/full (accessed July 2017).

LARSON, Q. (2017). A warning from Bill Gates, Elon Musk and Stephen Hawking. Available online: https://medium.freecodecamp.com/bill-gates-and-elon-musk-just-warned-us-aboutthe-one-thing-politicians-are-too-scared-to-talk-8db9815fd398\#.st1ukeri6 (accessed June 2017). 
MARTIN, S. (2014). Climate ready? Exploring the impacts and lessons from recent extreme events at Royal Botanic Garden Edinburgh. Sibbaldia, 6, 115-131.

RAE, D., CUBEY, R., HUGHES, K., GARDNER, M., THOMPSON, H., INCHES, F. \& KNOTT, D. (2012) Catalogue of Plants. Royal Botanic Garden Edinburgh, Edinburgh.

ROYAL BOTANIC GARDEN EDINBURGH (2017). Season's highlights March. Available online: www.rbge.org.uk/the-gardens/edinburgh/seasons-highlights/seasons-highlightsmarch (accessed March 2017).

UNGOED-THOMAS, J. (2017). Newcastle uses public health cash on parks. The Times, 27 February.

WANE, S., BLACKMORE, S. \& GILL, J. (2017). Hyperweeding. Available online: www.harperadams.ac.uk/research/project.cfm?id=187 (accessed June 2017). 